\title{
Anti-Tumorigenic Effects of Capsaicin in Colon Cancer
}

\author{
Seong-Ho Lee ${ }^{1,2^{*}}$ and Ruth Clark ${ }^{1}$ \\ ${ }^{1}$ Department of Nutrition and Food Science, College of Agriculture and Natural Resources, University of Maryland, College Park, MD 20742, USA
}

${ }^{2}$ Department of Pathobiology, College of Veterinary Medicine, University of Tennessee, Knoxville, TN 37996, USA

\section{'Correspondence to:}

Seong-Ho Lee

Department of Nutrition and Food Science

College of Agriculture and Natural Resources

University of Maryland, College Park

MD 20742, USA

Tel: (301) 405-4532

Fax: (301) 314-3313

E-mail: slee2000@umd.edu

Received: August 08, 2016

Accepted: October 18, 2016

Published: October 20, 2016

Citation: Lee SH, Clark R. 2016. AntiTumorigenic Effects of Capsaicin in Colon Cancer. J Food Chem Nanotechnol 2(4): 162-167.

Copyright: @ 2016 Lee and Clark. This is an Open Access article distributed under the terms of the Creative Commons Attribution 4.0 International License (CC-BY) (http://creativecommons. org/licenses/by/4.0/) which permits commercial use, including reproduction, adaptation, and distribution of the article provided the original author and source are credited.

Published by United Scientific Group

\begin{abstract}
Colon cancer is one of most common malignancies in the world. Capsaicin is a major component of chili peppers and has been shown to possess anti-cancer activity against various types of cancers. There is currently a limited number of preclinical studies that test the anti-cancer effects of capsaicin in colon cancer. The first objective of the present study is to investigate whether capsaicin influences tumor formation using a colon cancer mouse model. The second objective is to elucidate the anti-cancer mechanism of capsaicin using an in vitro cell culture system. For the in vivo study, we treated $A p^{c^{M i n+} /}$ mice having truncated deletion of $A P C$ (adenomatous polyposis coli) with capsaicin. For the in vitro study, we exposed human colorectal cancer cell lines to different concentrations of capsaicin and performed western blot analysis. Oral gavage of capsaicin at a dose of $20 \mathrm{mg} /$ $\mathrm{kg}$ body weight for 4 weeks tended to decrease the number of polyps $(43.5 \pm$ 14.6 vs $27.8 \pm 8.8, \mathrm{p}=0.114)$ and tumor load $(78.6 \pm 20.9$ vs $47.4 \pm 21.3, \mathrm{p}=$ $0.083)$ in the intestine of $A p c^{M^{i n t /}}$ mice. In vitro studies showed that, in human colon cancer cells, capsaicin induced phosphorylation of cyclin D1 at threonine 286 (T286) and decreased cyclin D1 expression in a dose- and time-dependent manner. In addition, capsaicin treatment increased intracellular ubiquitination of proteins in a dose-dependent manner and decreased the caspase-like activity of $20 \mathrm{~S}$ proteasome significantly $(\mathrm{p}=0.026)$. This study identifies capsaicin as a potential anti-cancer agent that targets cyclin D1 degradation and proteasome activity in colon cancer.
\end{abstract}

\section{Keywords}

Capsaicin, Colon cancer, Polyp, Cyclin D1, Proteasome

\section{Abbreviations}

ACF: Aberrant crypt foci; APC: Adenomatous polyposis coli; CDK: Cyclin dependent kinase; FAP: Familial adenomatous polyposis; HA: Hemagglutinin; NAG-1: Non-steroidal anti-inflammatory drug-activated gene-1; TCF4: T-cell factor 4

\section{Introduction}

Colon cancer is one of the leading malignant cancers in the world [1]. There are very strong correlations between incidence of colon cancer and eating patterns, in particular the consumption of a plant-based diet [2]. Capsaicin is a major component of chili peppers and produces a spicy taste. Recently, numerous in vitro studies have reported the anti-cancer activities of capsaicin in various cancer 
models [3-14], although several studies claimed that capsaicin exhibited potential cancer promoting activities $[15,16]$. Our group has previously demonstrated that capsaicin induced apoptosis and suppressed cell proliferation through NSAIDsactivated gene-1 (NAG-1) and $\beta$-catenin/TCF4-mediated pathways in human colon cancer cells $[8,17]$. Recently, we reviewed the anti-cancer mechanisms by which capsaicin led to apoptosis and growth arrest, and inhibited metastasis and angiogenesis [18]. Cao S et al., has also reviewed the anticancer mechanisms of capsaicin based on different cancer types [19]. However, most published studies have been carried out using in vitro cell culture systems and there has been no in vivo study to test the efficacy of capsaicin in a colon cancer model.

Normal regulation of the cell cycle is essential for tissue development and homeostasis. Cyclins play a significant role in the regulation of the cell cycle. Different cyclins participate in different phases of the cell cycle with specificity and the synthesis of each cyclin is coordinated with DNA synthesis and cell division. Aberrant regulation of cyclins impairs DNA check points and leads to tumorigenesis. Type D cyclins are involved in the transition of the cell cycle from the G1 phase to the $\mathrm{S}$ phase and influence growth arrest, which is a promising strategy to control initiation and progression of cancer [20]. Cyclin D1 overexpression is observed in many types of cancers [20] and amount of cyclin D1 in the cells is determined by several mechanisms. One of these mechanisms is transcriptional regulation, which is affected by activators and repressors. Many oncogenic triggers, including growth factors and cytokines, induce transcription of cyclin D1 [21]. With regard to this mechanism, we also reported that transcriptional activity of cyclin D1 promoter is down regulated by dietary compounds such as capsaicin [8] and 6-gingerol [22]. Another mechanism to determine the amount of cellular cyclin D1 is proteosomal degradation. It has been shown that several anticancer compounds, including retinoic acid and curcumin, down regulate cyclin D1 through increasing protein instability and subsequent proteosomal degradation $[23,24]$.

The current study was designed to observe whether capsaicin affects intestinal tumorigenesis in an adenomatous polyposis coli (APC)-truncated colon cancer mouse model $\left(A P c^{M i n+}\right)$ and elucidate the anti-cancer mechanism involving cyclin D1 degradation. The current study demonstrate that capsaicin tended to reduce polyp formation in $A p c^{M i n+/}$ mice and suppressed cyclin D1 expression via an increase of degradation in human colon cancer cells.

\section{Materials and Methods}

\section{Materials}

Capsaicin was purchased from Sigma (St. Louis, MO, USA) and dissolved in absolute ethanol to make $100 \mathrm{mM}$ stock solution. Antibodies for cyclin D1, cyclin D3, and actin were purchased from Santa Cruz (Santa Cruz, CA, USA). Antibodies for phospho-cyclin D1 (T286) and hemagglutinin (HA) were purchased from Cell Signaling (Beverly, MA, USA) and BioLegend (San Diego, CA, USA). Unless otherwise specified, all chemicals and cell culture media were purchased from Fisher Scientific (Waltham, MA, USA) and VWR International (Radnor, PA, USA) and used without further purification.

\section{In vivo study}

The $A P C^{\mathrm{Min} /+}$ mice were purchased from Jackson Laboratories (Bar Harbor, ME, USA). The mice were bred and genotyped as previously described [25]. The mice (10 weeks old) were randomly assigned to two groups (four mice per treatment) and gavaged orally with $0.5 \%$ methylcellulose only (vehicle) or capsaicin in $0.5 \%$ methylcellulose at a dose of $20 \mathrm{mg} / \mathrm{kg}$ body weight every other day for 4 weeks. For the gavage, $62 \mathrm{mg}$ of capsaicin (65\% purity) was suspended in $10 \mathrm{~mL}$ of $0.5 \%$ methylcellulose and $100 \mu \mathrm{L}$ of suspension was gavaged into the mice ( $20 \mathrm{~g}$ body weight in average). A week after the final gavage, the mice were euthanized and the intestinal tract was collected and washed with ice-cold phosphate-buffered saline (PBS). Tumor numbers and sizes were measured under a stereoscopic microscope as previously performed [25]. All procedures for the in vivo study were approved by the Institutional Animal Care and Use Committee (protocol \#:1676) at the University of Tennessee.

\section{Cell culture and measurement of cell proliferation}

Human colon adenocarcinoma cells (SW480, HCT116, LoVo and Caco-2) were purchased from American Type Culture Collection (Manassas, VA, USA) and maintained as previously described $[17,18]$. Cell proliferation was measured using the Cell Proliferation Assay system (Promega, Madison, WI, USA) according to the manufacturer's instruction. The absorbance value at $\mathrm{A}_{490}$ was detected using an ELISA plate reader (Bio-Tek Instruments Inc, Winooski, VT, USA).

\section{Transient transfection}

An HA-tagged ubiquitin expression vector was transfected into the cells using Lipofectamin 2000 (Thermo Scientific, Waltham, MA, USA), according to the manufacturer's instruction. Briefly, the cells $\left(2 \times 10^{5}\right.$ cell/well $)$ were plated onto 6-well culture dish and maintained overnight. The next day the cells were incubated in media containing the DNA/ Lipofectamin complex for an additional 48 hours.

\section{Western blot}

After treatment with vehicle (ethanol) and different doses of capsaicin, the cells were lysed by incubation with radioimmunoprecipitation assay (RIPA) buffer supplemented with a protease/phosphatase inhibitors cocktail. The cell debris was removed by centrifugation at $10,000 \times \mathrm{g}$ for $10 \mathrm{~min}$ at $4{ }^{\circ} \mathrm{C}$ and the supernatant containing cellular proteins was collected. Next, $30 \mu \mathrm{g}$ of protein from the supernatant were loaded onto a SDS-polyacrylamide gel, separated with electrophoresis, and transferred to a nitrocellulose membrane. After overnight incubation with the target antibodies, the membranes were incubated with horse radish peroxidase (HRP)-conjugated IgG for 1 hour and visualized using ECL (Amersham Biosciences, Piscataway, NJ, USA). 


\section{S Proteasome assay}

$20 \mathrm{~S}$ proteasome assays were performed using a Proteasome-Glo Assay Systems Kit (Promega, Madison, WI, USA) as previously described [26]. Briefly, the cells were treated with vehicle (ethanol) and capsaicin in triplicates and $30 \mu \mathrm{g}$ of protein from each sample was loaded in a whitewalled 96-well plate. Then, equal amounts of chymotrypsinlike, trypsin-like, and caspase-like substrates were added. After incubation for 1 hour at room temperature, the luminescence for the three activities was measured using an ELISA plate reader (Bio-Tek Instruments Inc, Winooski, VT, USA).

\section{Statistical analysis}

Statistical analysis was performed using SPSS v18.0 with the Student $t$ test.

\section{Results}

Capsaicin reduced the formation of tumor in the small intestine of $A P c^{\mathrm{Min+} /}$ mice

To investigate if capsaicin affects tumor formation, we used a genetically-induced colon cancer model ( $A p c^{M i n+/}$ mice). These mice produce a significant number of polyps due to expressing a truncated deletion of APC, which is an important tumor suppressor gene in the gastrointestinal tract. Ten-week old $A p c^{M i n+/}$ mice were exposed to $0.5 \%$ methylcellulose only (vehicle) or capsaicin in $0.5 \%$ methylcellulose at a dose of 20 $\mathrm{mg} / \mathrm{kg}$ body weight by oral gavage for 4 weeks. As shown in Figure 1, control mice produced 43.5 polyps on average, but capsaicin treatment reduced the average polyp number to 27.8 , although the difference was not statistically significant $(\mathrm{p}=$ 0.114). Tumor load (calculated as number of polyps $\mathrm{x}$ average diameter) analysis showed a tendency for treatment with capsaicin to reduced polyp development, but the difference was not statistically significant $(\mathrm{p}=0.083)$.
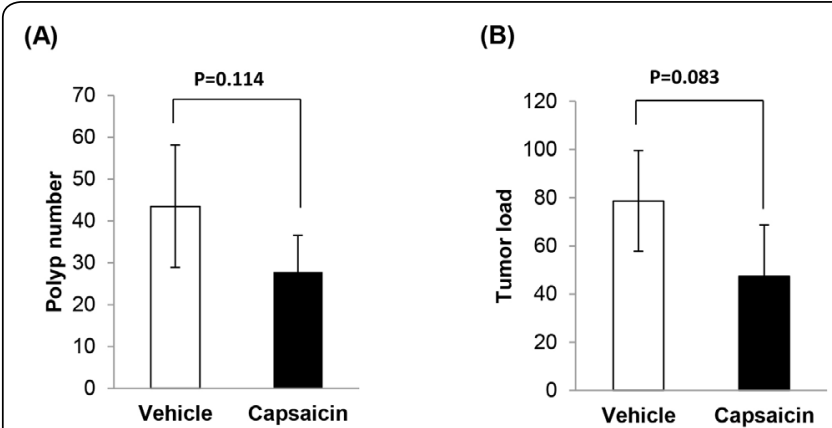

Figure 1: Capsaicin reduced the formation of tumor in small intestine of $A p c^{M i n+/}$ mice. $A p c^{M i n+/}$ mice were gavaged with $0.5 \%$ methylcellulose only (vehicle) or capsaicin in $0.5 \%$ methycellulose $(20 \mathrm{mg} / \mathrm{kg}$ body weight) every other day for 4 weeks. Total polyp numbers and size were measured from intestine. (A) Total polyp number, (B) Tumor load (calculated as number of polyps $\mathrm{x}$ average diameter).

Anti-proliferative activity of capsaicin is serum concentration-dependent in vitro

We further investigated whether a varied content of serum in the media affects capsaicin's anti-proliferative activity. As shown in Figure 2, capsaicin led to dramatic suppression of proliferation in colon cancer cells incubated with a $1 \%$ serumcontaining medium [Day 1: $0.475 \pm 0.032,0.478 \pm 0.021(\mathrm{p}=$ $0.451)$, and $0.390 \pm 0.008(\mathrm{p}<0.001)$; Day 2: $0.712 \pm 0.043$, $0.599 \pm 0.029(\mathrm{p}=0.002)$, and $0.399 \pm 0.017(\mathrm{p}<0.001)$; Day 3: $0.993 \pm 0.047,0.774 \pm 0.106(\mathrm{p}=0.003)$, and $0.444 \pm$ 0.079 ( $\mathrm{p}<0.001)$ at 0,50 , and $100 \mu \mathrm{M}$ capsaicin, respectively]. However, the effects were weakened in cells treated with $5 \%$ serum-containing medium [Day 1: $0.525 \pm 0.019,0.484 \pm$ $0.007(\mathrm{p}=0.003)$, and $0.433 \pm 0.017(\mathrm{p}<0.001)$; Day 2: 0.773 $\pm 0.029,0.739 \pm 0.025(\mathrm{p}=0.062)$, and $0.562 \pm 0.014(\mathrm{p}<$ 0.001); Day 3: $1.091 \pm 0.032,0.998 \pm 0.051(\mathrm{p}=0.011)$, and $0.717 \pm 0.055(\mathrm{p}<0.001)$ at 0,50 , and $100 \mu \mathrm{M}$ capsaicin, respectively] and $10 \%$ serum serum-containing medium [Day 1: $0.487 \pm 0.040,0.431 \pm 0.023(\mathrm{p}=0.027)$, and $0.395 \pm 0.012$ $(\mathrm{p}=0.002) ;$ Day 2: $0.750 \pm 0.030,0.692 \pm 0.050(\mathrm{p}=0.048)$, and $0.583 \pm 0.037(\mathrm{p}<0.001)$; Day 3: $1.014 \pm 0.042,0.942 \pm$ $0.034(\mathrm{p}=0.018)$, and $0.775 \pm 0.062(\mathrm{p}<0.001)$ at 0,50 , and $100 \mu \mathrm{M}$ capsaicin, respectively].
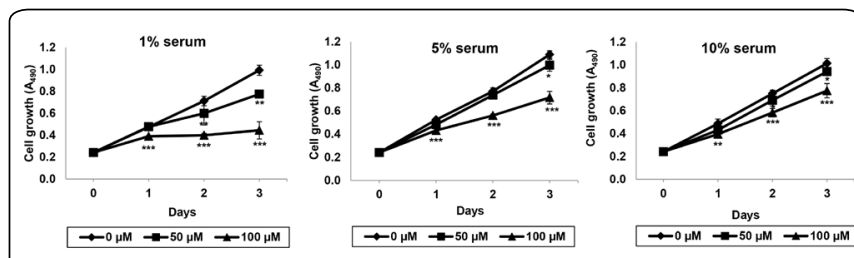

Figure 2: Anti-proliferative activity of capsaicin is serum concentrationdependent in in vitro. Different concentrations of capsaicin (0, 50 and 100 $\mu \mathrm{M})$ were dissolved in culture media containing 1,5 and $10 \%$ of serum and then treated to human colon cancer cells for $0,1,2$, and 3 days. Cell growth was measured using CellTiter96 Aqueous One Solution Cell Proliferation Assay and expressed as absorbance $\left(\mathrm{A}_{490}\right) .^{*}, \mathrm{P}<0.05 ;{ }^{* *}, \mathrm{P}<0.01 ;{ }^{* * *}, \mathrm{P}<0.001$ versus vehicle (ethanol)-treated cells.

Capsaicin decreased expression of cyclin D1 and cyclin D3 in a dose-dependent manner in human colon cancer cells

SW480 ( $A P C$ mutant) and HCT116 ( $A P C$ wild type) cells were incubated with different doses of capsaicin, followed by western blot analysis to measure expression of cyclin D1 and D3. As shown in Figure 3, the results indicate that capsaicin treatment reduces the expression of cyclin D1 and D3 in a dose-dependent and APC-independent manner.

\begin{tabular}{|c|c|c|c|}
\hline (A) & & (B) & \multirow[b]{3}{*}{ Capsaicin $(\mu \mathrm{M})$} \\
\hline SW480 & & HCT116 & \\
\hline $\begin{array}{llll}0 & 12.52550 & 100\end{array}$ & Capsaicin $(\mu \mathrm{M})$ & $\begin{array}{lllll}0 & 12.5 & 25 & 50 & 100\end{array}$ & \\
\hline---- & Cyclin D1 & $---\cdots$ & Cyclin D1 \\
\hline 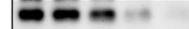 & Cyclin D3 & - & Cyclin D3 \\
\hline 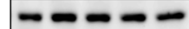 & Actin & $-1-0-\cdots$ & Actin \\
\hline
\end{tabular}

Figure 3: Capsaicin decreased expression of cyclin D1 and cyclin D3 in dosedependent manner in human colon cancer cells. SW480 (A) and HCT116 (B) cells were incubated with $0,12.5,25,50$ and $100 \mu \mathrm{M}$ of capsaicin in $0.5 \%$ serum-containing media for 24 hours. The cell lysates were extracted and used for western blot analysis for cyclin D1, cyclin D3 and actin.

Capsaicin increased phosphorylation of cyclin D1 at threonine 286

We investigated if phosphorylation of cyclin D1 at threonine 286 is affected by capsaicin in four different types of human colon cancer cells with different genetic backgrounds. As a result, we found that capsaicin stimulated phosphorylation of cyclin D1 in LoVo, SW480, and Caco-2 cells, but not in 
HCT116 cell and subsequently repressed expression of cyclin D1 in a time-dependent manner in this cell type (Figure 4).

\begin{tabular}{|c|c|c|c|}
\hline Lovo & \multirow{6}{*}{$\begin{array}{l}\text { Phospho cyclin D1 (T286) } \\
\text { Cyclin D1 } \\
\text { Actin }\end{array}$} & \multirow{2}{*}{$\begin{array}{l}\text { B) } \\
\text { SW480 } \\
\text { Capsaicin }(100 \mu \mathrm{M})\end{array}$} & \\
\hline Capsaicin $(100 \mu \mathrm{M})$ & & & \\
\hline $\begin{array}{lllllll}0 & 3 & 6 & 9 & 24 & 36 & 48\end{array}$ & & $\begin{array}{lllll}0 & 3 & 6 & 9 & 24 \mathrm{~h}\end{array}$ & \multirow{4}{*}{$\begin{array}{l}\text { Phospho cyclin D1 (T286) } \\
\text { Cyclin D1 } \\
\text { Actin }\end{array}$} \\
\hline$-1---$ & & - $P$ & \\
\hline bus m- & & $--\cdots$ & \\
\hline - & & 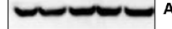 & \\
\hline (C) & & (D) & \\
\hline Caco-2 & & HCT116 & \\
\hline Capsaicin $(100 \mu M)$ & & Capsaicin $(\mathbf{1 0 0 \mu \mathrm { M } )}$ & \\
\hline $\begin{array}{llllllll}0 & 3 & 6 & 9 & 24 & 36 & 48 & \mathrm{~h}\end{array}$ & & $\begin{array}{lllll}0 & 3 & 6 & 9 & 24 \mathrm{~h}\end{array}$ & \\
\hline$-2--$ & Phospho cyclin D1 (T286) & & Phospho cyclin D1 (T286) \\
\hline$----\cdots$ & Cyclin D1 & $-\cdots--$ & Cyclin D1 \\
\hline$---\infty--\infty$ & Actin & - & Actin \\
\hline $\begin{array}{l}\text { Figure 4: Capsaicin } \\
\text { Different human col } \\
\text { were treated with } 1 \\
\text { lysates were isolated } \\
\text { cyclin D1 and actin. }\end{array}$ & $\begin{array}{l}\text { increased phosphoryl } \\
\text { lon cancer cells (LoV } \\
00 \mu \mathrm{M} \text { of capsaicin } \\
\text { and used for western }\end{array}$ & $\begin{array}{l}\text { ion of cyclin D1 } \\
\text { SW480, Caco- } \\
\text { r indicated time } \\
\text { lot for phospho c }\end{array}$ & $\begin{array}{l}1 \text { at threonine } 286 . \\
-2 \text { and HCT116) } \\
\text { he points. The cell } \\
\text { cyclin D1 (T286), }\end{array}$ \\
\hline
\end{tabular}

Capsaicin increased ubiquitination and decreased caspaselike activity of the $20 \mathrm{~S}$ proteasome in human colon cancer cells

We tested the effects of capsaicin on cellular ubiquitination profiles. As shown in Figure 5, capsaicin increased the accumulation of ubiquitinated proteins for cells in a dosedependent manner. Ubiquitin accumulation was more dramatic in SW480 cells compared to HCT116 cells, implying varying responsiveness to capsaicin. Next, we tested if capsaicin influences $20 \mathrm{~S}$ proteasome activity because ubiquitinated proteins undergo proteosomal degradation. There are three major proteolytic activities, specifically chymotrypsin-like, trypsin-like, and caspase-like activities, within the 20S core. Therefore, we used a Proteasome-Glo Assay Systems that measure the above-described activities. As shown in Figure 6, capsaicin did not affect chemotrypsin-[298.3 \pm 135.2 vs 274.0 $\pm 90.8(\mathrm{p}=0.404)]$ or trypsin-like activity $[270.7 \pm 81.1 \mathrm{vs}$ $365.7 \pm 150.5(\mathrm{p}=0.195)]$, but significantly reduced caspaselike activity $[3064.3 \pm 704.9$ vs $1889.0 \pm 235.5(\mathrm{p}=0.026)]$.
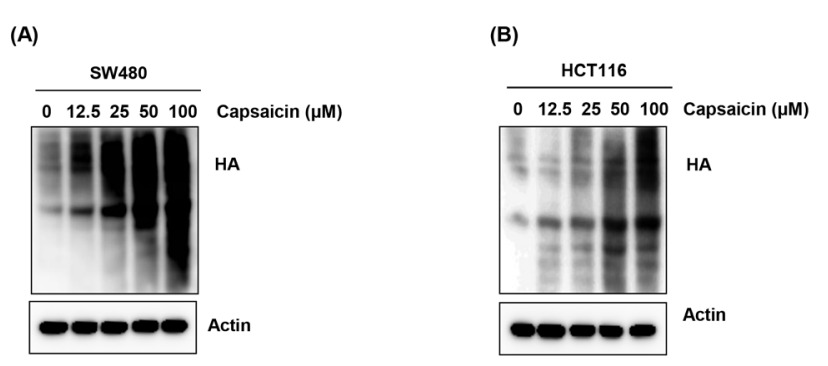

Figure 5: Capsaicin increased ubiquitin activity in human colon cancer cells. SW480 (A) and HCT116 (B) cells were transfected with HA-tagged ubiquitin for 24 hours and then treated with different doses of capsaicin (0, $12.5,25,50$ and $100 \mu \mathrm{M})$. Western blot was performed for $\mathrm{HA}$ and actin.

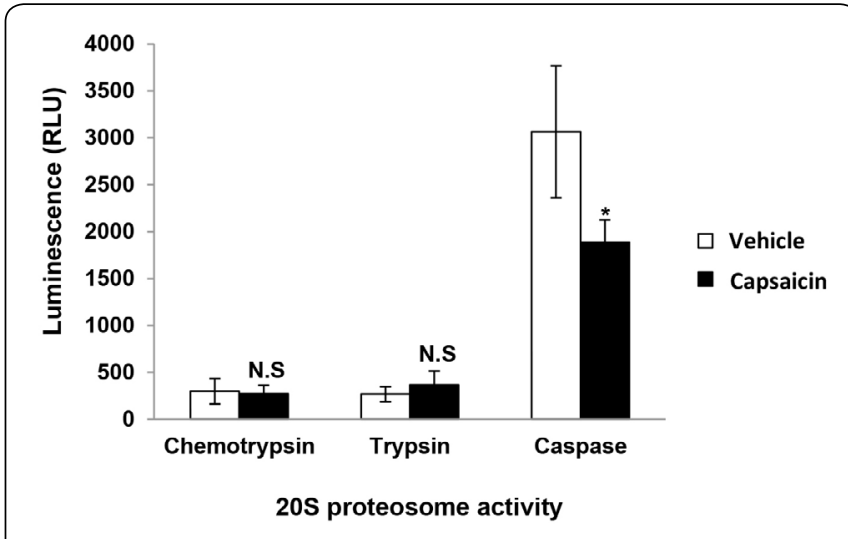

Figure 6: Capsaicin decreased caspase-like activity of $20 \mathrm{~S}$ proteasome in human colon cancer cells. HCT116 cells were treated with 0 or $100 \mu \mathrm{M}$ of capsaicin for 24 hours and three types of proteasome activities were measured using Proteasome-Glo ${ }^{\mathrm{TM}}$ Assay System as described in Materials and Methods. ${ }^{*}, \mathrm{P}<0.05$ versus vehicle (ethanol)-treated cells..

\section{Discussion}

Capsaicin is a major derivative of homovanillic acid and is abundant in spicy food. Recently, we reviewed the anti-cancer activities of capsaicin in various types of cancer including colon cancer [18]. Capsaicin induced apoptosis and growth arrest, and inhibited metastasis and angiogenesis through upor down-regulation of complex cancer-associated genes and related signaling pathways. However, a lack of pre-clinical studies prohibits the practical use of capsaicin as an anticancer compound. Yoshitani SI, et al., reported that capsaicin treatment suppressed the formation of aberrant cryptic foci $(\mathrm{ACF})$ in rats exposed to azoxymethane, which is colonspecific carcinogen [27]. However, ACF represent histological changes in the very early pre-neoplasmic stage. Therefore, we employed an animal model with a more advanced staged tumor in order to test the anti-cancer effects of capsaicin. The mouse model used here has a truncated deletion in the $A P C$ gene and resembles human familial adenomatous polyposis (FAP) syndrome. These mice typically develop small adenomas or polyps in the small intestine. Although the difference was not statistically significant, treatment with capsaicin $(20 \mathrm{mg} / \mathrm{kg}$ body weight) tended to prevent the formation or enlargement of polyps in mice, implying a potential anti-cancer activity of capsaicin in the early stages (adenoma) of colon cancer.

In our previous study, we observed that capsaicin treatment decreased proliferation of several colon cancer cell lines with different genetic backgrounds [8]. It is known that serum in culture media may affect the efficacy of test compounds due to the binding of test compounds to serum components. In fact, phenol compounds, including capsaicin, can bind to serum proteins and blunt their own efficacy $[28,29]$. Based on the results from Figure 2, we recommend the use of culture media containing 0.5 or $1.0 \%$ of serum for the treatment with capsaicin.

Cyclin D1 and cyclin D3 are the major form of D type cyclins and play a significant role in the transition of the cell cycle from the $\mathrm{G} 1$ to $\mathrm{S}$ phase in collaboration with partner proteins, such as CDK4/6 (cyclin-dependent kinases 4/6) [20]. Deregulation and accumulation of cyclin D1 is an 
important event in the development of various malignant cancers, including colon cancer. In most colon cancer tissues, cyclin D1 expression is constitutively high due to defective APC or $\beta$-catenin genes, which are the main upstream regulators of cyclin D1. However, Wnt/GSK3/ $\beta$-catenin axis-independent regulation of cyclin D1 is also common in cancer. Therefore, we explored cyclin D1 degradation as an alternative anti-cancer mechanism for capsaicin. For the first time, our data revealed that capsaicin increased cyclin D1 phosphorylation at threonine 286, which is responsible for proteosomal degradation of cyclin D1 in human colon cancer cells [30]. This is consistent with the finding that capsaicin inhibited the G1 to $\mathrm{S}$ transition in the same type of colon cancer cells [31]. In terms of cyclin D1 phosphorylation, several kinases, including p38, GSK3, and Mirk, have been proposed phosphate donors in the mechanism of cyclin D1 phosphorylation. We speculate that Mirk could be the responsible kinase for cyclin D1 phosphorylation because there was no induction of phosphorylation in HCT116 cells (Figure 4D), which are Mirk null [32]. In addition, HCT116 cells may use a different mechanism for cyclin D1 down regulation, as opposed to threonine 286-mediated degradation.

The ubiquitin-proteasome pathway is an important regulatory system in determining protein stability and cancer development [33]. Many proteins, including cyclin D1, are initially conjugated with ubiquitin and then transferred to the $26 \mathrm{~S}$ proteasome, which consists of a $20 \mathrm{~S}$ core and a $19 \mathrm{~S}$ regulatory complex [34]. In the current study we found that capsaicin increased the amount of ubiquitinated proteins in a dose-dependent manner (Figure 5). On the other hand, it is known that the $20 \mathrm{~S}$ proteasome contains three major activities, chemotrypsin-, trypsin-, and caspase-like activities. Due to their unique biological functions, we measured each activity. Surprisingly, capsaicin did not affect chemotrypsinor trypsin-like activities and significantly decreased caspaselike activity $[3064.3 \pm 704.9$ vs $1889.0 \pm 235.5(\mathrm{p}=0.026)]$ (Figure 6). This data is consistent with previous observation that capsaicin inhibited $20 \mathrm{~S}$ proteasome activity in neuron cells [35]. To our knowledge, this is the first report that capsaicin specifically represses the caspase-like activity of the $20 \mathrm{~S}$ proteasome in colon cancer cells. Based on our data, we speculate that capsaicin-induced cyclin D1 degradation and ubiquitination may be proteasome-independent. Further studies are required to address this hypothesis.

The capsaicin concentration used in the current study is similar to those used in several other studies [36-38]. As we discussed in previous studies $[8,17]$, the accurate blood concentration of capsaicin after intake is unknown. According to other studies, the blood concentration of capsaicin can reach up to $581 \mathrm{ng} / \mathrm{mL}$ (equivalent to $2 \mu \mathrm{M}$ ) in rats after intravenous administration of capsaicin $(2 \mathrm{mg} / \mathrm{kg}$ body weight) [39]. We believe that the relevance of in vitro doses should be estimated with careful consideration of several factors, such as bioavailability, potential active metabolites, and local concentration. For example, a much higher amount of capsaicin may reach colon because the local concentration of phytochemicals is much higher than in plasma [40].

On the other hand, increased autophagy has been proposed as one of the anti-cancer mechanisms of capsaicin. High doses of capsaicin induce autophagy, apoptosis, and inhibition of autophagy sensitized capsaicin-induced apoptosis in bladder [41] and liver cancer cells [42]. Although the autophagic parameters were not measured in the current study, autophagy could be considered as a potential mechanism of capsaicin's anti-cancer activity in human colon cancer cells.

\section{Conclusion}

The current study provides an important clue for potential use of capsaicin as an anti-cancer agent in colon cancer. In vitro data provide evidence that cyclin D1 degradation and $20 \mathrm{~S}$ proteasome activity could be the mechanistic target for anti-cancer activity of capsaicin in human colon cancer.

\section{Conflict of Interest}

There is no conflict of interest pertaining to this manuscript.

\section{Acknowledgements}

We thank Mugdha Sukhthankar and Raphael L. Richardson for their technical support and assistance. This work was in part supported by NCI/NIH grant (R03CA137755) and start-up funds from the University of Maryland to S-H Lee.

\section{References}

1. Parkin DM, Bray F, Ferlay J, Pisani P. 2005. Global cancer statistics, 2002. CA: Cancer J Clin 55(2): 74-108. doi: 10.3322/canjclin.55.2.74

2. COMA. 1998. Nutritional aspects of the development of cancer. The Stationary Office, London, UK.

3. Ito K, Nakazato T, Yamato K, Miyakawa Y, Yamada T, et al. 2004. Induction of apoptosis in leukemic cells by homovanillic acid derivative, capsaicin, through oxidative stress: implication of phosphorylation of p53 at Ser-15 residue by reactive oxygen species. Cancer Res 64(3): 1071-1078. doi: 10.1158/0008-5472.CAN-03-1670

4. Lee YH, Chen HY, Su LJ, Chueh PJ. 2015. Sirtuin 1 (SIRT1) deacetylase activity and $\mathrm{NAD}^{+} / \mathrm{NADH}$ ratio are imperative for capsaicin-mediated programmed cell death. J Agri Food Chem 63(33): 7361-7370. doi: 10.1021/acs.jafc.5b02876

5. Ip SW, Lan SH, Lu HF, Huang AC, Yang JS, et al. 2012. Capsaicin mediates apoptosis in human nasopharyngeal carcinoma NPC-TW 039 cells through mitochondrial depolarization and endoplasmic reticulum stress. Human Exp Toxicol 31(6): 539-549. doi: $10.1177 / 0960327111417269$

6. Ying H, Wang Z, Zhang Y, Yang TY, Ding ZH, et al. 2013. Capsaicin induces apoptosis in human osteosarcoma cells through AMPKdependent and AMPK-independent signaling pathways. Mol Cell Biochem 384(1-2): 229-237. doi: 10.1007/s11010-013-1802-8

7. Chen D, Yang Z, Wang Y, Zhu G, Wang X. 2012. Capsaicin induces cycle arrest by inhibiting cyclin-dependent-kinase in bladder carcinoma cells. Inter J Urology 19(7): 662-668. doi: 10.1111/j.14422042.2012.02981.x

8. Lee SH, Richardson RL, Dashwood RH, Baek SJ. 2012. Capsaicin represses transcriptional activity of $\beta$-catenin in human colorectal cancer cells.J Nutr Biochem 23(6): 646-655. doi: 10.1016/j.jnutbio.2011.03.009

9. Wu JP, Yang JS, Chou ST, Chen SC, Lin YT, et al. 2006. Capsaicin induced cell cycle arrest and apoptosis in human esophagus epidermoid 
carcinoma CE 81T/VGH cells through the elevation of intracellular reactive oxygen species and $\mathrm{Ca}^{2+}$ productions and caspase- 3 activation. Mutat Res 601(1-2): 71-82. doi: 10.1016/j.mrfmmm.2006.06.015

10. Thoennissen NH, O'Kelly J, Lu D, Iwanski GB, La DT, et al. 2010. Capsaicin causes cell-cycle arrest and apoptosis in ER-positive and -negative breast cancer cells by modulating the EGFR/HER-2 pathway. Oncogene 29(2): 285-296. doi: 10.1038/onc.2009.335

11. Wang HM, Chuang SM, Su YC, Li YH, Chueh PJ. 2011. Downregulation of tumor-associated NADH oxidase, tNOX (ENOX2), enhances capsaicin-induced inhibition of gastric cancer cell growth. Cell Biochem Biophys 61(2): 355-366. doi: 10.1007/s12013-011-9218-0

12. Yang J, Li TZ, Xu GH, Luo BB, Chen YX, et al. 2013. Lowconcentration capsaicin promotes colorectal cancer metastasis by triggering ROS production and modulating Akt $/ \mathrm{mTOR}$ and STAT-3 pathways. Neoplasma 60(4): 364-372. doi: 10.4149/neo_2013_048

13. Lee GR, Jang SH, Kim CJ, Kim AR, Yoon DJ, et al. 2014. Capsaicin suppresses the migration of cholangiocarcinoma cells by downregulating matrix metalloproteinase- 9 expression via the AMPK-NFkappaB signaling pathway. Clin Exp Metastasis 31(8): 897-907. doi: $10.1007 / \mathrm{s} 10585-014-9678-\mathrm{x}$

14. Caprodossi S, Amantini C, Nabissi M, Morelli MB, Farfariello V, et al. 2011. Capsaicin promotes a more aggressive gene expression phenotype and invasiveness in null-TRPV1 urothelial cancer cells. Carcinogenesis 32(5): 686-694. doi: 10.1093/carcin/bgr025

15. Hwang MK, Bode AM, Byun S, Song NR, Lee HJ, et al. 2010. Cocarcinogenic effect of capsaicin involves activation of EGFR signaling but not TRPV1. Cancer Res 70(17): 6859-6869. doi: 10.1158/0008-5472.CAN-09-4393

16. Agrawal RC, Wiessler M, Hecker E, Bhide SV. 1986. Tumourpromoting effect of chilli extract in BALB/c mice. Int J Cancer 38(5): 689-695. doi: 10.1002/ijc.2910380512

17. Lee SH, Krisanapun C, Baek SJ. 2010. NSAID-activated gene1 as a molecular target for capsaicin-induced apoptosis through a novel molecular mechanism involving GSK3 $\beta$, C/EBP $\beta$, and ATF3. Carcinogenesis 31(4): 719-728. doi: 10.1093/carcin/bgq016

18. Clark R, Lee SH. 2016. Anticancer properties of capsaicin against human cancer. Anticancer Res 36(3): 837-843.

19. Cao S, Xiang S, Hong J, Weng L, Zhu H, et al. 2015. Anti-cancer effects and mechanisms of capsaicin in chili peppers. Am J Plant Sci 6: 3075-3081. doi: 10.4236/ajps.2015.619300

20. Musgrove EA, Caldon CE, Barraclough J, Stone A, Sutherland RL. 2011. Cyclin D as a therapeutic target in cancer. Nat Rev Cancer 11(8): 558-572. doi: 10.1038/nrc3090

21. Klein EA, Assoian RK. 2008. Transcriptional regulation of the cyclin D1 gene at a glance. J Cell Sci 121(23): 3853-3857. doi: 10.1242/ jcs.039131

22. Lee S-H, Cekanova M, Baek SJ. 2008. Multiple mechanisms are involved in 6-gingerol-induced cell growth arrest and apoptosis in human colorectal cancer cells. Mol Carcinog 47(3): 197-208. doi: $10.1002 / \mathrm{mc} .20374$

23. Mukhopadhyay A, Banerjee S, Stafford LJ, Xia C, Liu M, et al. 2002. Curcumin-induced suppression of cell proliferation correlates with down-regulation of cyclin D1 expression and CDK4-mediated retinoblastoma protein phosphorylation. Oncogene 21(57): 8852-8861. doi: 10.1038/sj.onc.1206048

24. Spinella MJ, Freemantle SJ, Sekula D, Chang JH, Christie AJ, et al. 1999. Retinoic acid promotes ubiquitination and proteolysis of cyclin D1 during induced tumor cell differentiation. J Biol Chem 274(31): 22013-22018. doi: 10.1074/jbc.274.31.22013

25. Baek SJ, Okazaki R, Lee SH, Martinez J, Kim JS, et al. 2006. Nonsteroidal anti-inflammatory drug-activated gene-1 over expression in transgenic mice suppresses intestinal neoplasia. Gastroenterology
131(5): 1553-1560. doi: 10.1053/j.gastro.2006.09.015

26. Sukhthankar M, Yamaguchi K, Lee SH, McEntee MF, Eling TE, et al. 2008. A green tea component suppresses posttranslational expression of basic fibroblast growth factor in colorectal cancer. Gastroenterology 134(7): 1972-1980. doi: 10.1053/j.gastro.2008.02.095

27. Yoshitani SI,Tanaka T, Kohno H,Takashima S. 2001. Chemoprevention of azoxymethane-induced rat colon carcinogenesis by dietary capsaicin and rotenone. Int J Oncol 19(5): 929-939. doi: 10.3892/ijo.19.5.929

28. Rawel HM, Meidtner K, Kroll J. 2005. Binding of selected phenolic compounds to proteins. J Agric Food Chem 53(10): 4228-4235. doi: $10.1021 / \mathrm{jf} 0480290$

29. Ogata N, Shibata T. 2000. Binding of alkyl- and alkoxy-substituted simple phenolic compounds to human serum proteins. Res Commun Mol Pathol Pharmacol 107(1-2): 167-173.

30. Alao JP. 2007. The regulation of cyclin D1 degradation: roles in cancer development and the potential for therapeutic invention. Mol Cancer 6: 24. doi: 10.1186/1476-4598-6-24

31. Jin J, Lin G, Huang H, Xu D, Yu H, et al. 2014. Capsaicin mediates cell cycle arrest and apoptosis in human colon cancer cells via stabilizing and activating p53. Int J Biol Sci 10(3): 285-295. doi: 10.7150/ijbs.7730

32. Ewton DZ, Hu J, Vilenchik M, Deng X, Luk KC, et al. 2011. Inactivation of mirk/dyrk1b kinase targets quiescent pancreatic cancer cells. Mol Cancer Ther 10(11): 2104-2114. doi: 10.1158/1535-7163. MCT-11-0498

33. Harada T, Harada C, Wang YL, Osaka H, Amanai K, et al. 2004. Role of ubiquitin carboxy terminal hydrolase-L1 in neural cell apoptosis induced by ischemic retinal injury in vivo. Am J Pathol 164(1): 59-64. doi: 10.1016/S0002-9440(10)63096-9

34. Parcellier A, Schmitt E, Gurbuxani S, Seigneurin-Berny D, Pance A, et al. 2003. HSP27 is a ubiquitin-binding protein involved in I- $\kappa \mathrm{B} \alpha$ proteasomal degradation. Mol Cell Biol 23(16): 5790-5802. doi: 10.1128/MCB.23.16.5790-5802.2003

35. Maity R, Sharma J,Jana NR. 2010. Capsaicin induces apoptosis through ubiquitin-proteasome system dysfunction. J Cell Biochem 109(5): 933942. doi: $10.1002 / \mathrm{jcb} .22469$

36. Kim MY, Trudel LJ, Wogan GN. 2009. Apoptosis induced by capsaicin and resveratrol in colon carcinoma cells requires nitric oxide production and caspase activation. Anticancer Res 29(10): 3733-3740.

37. Kim YM, Hwang JT, Kwak DW, Lee YK, Park OJ. 2007. Involvement of AMPK signaling cascade in capsaicin-induced apoptosis of HT29 colon cancer cells. Ann N Y Acad Sci 1095: 496-503. doi: 10.1196/ annals. 1397.053

38. Yang KM, Pyo JO, Kim GY, Yu R, Han IS, et al. 2009. Capsaicin induces apoptosis by generating reactive oxygen species and disrupting mitochondrial transmembrane potential in human colon cancer cell lines. Cell Mol Biol Lett 14(3): 497-510. doi: 10.2478/s11658-0090016-2

39. Saria A, Skofitsch G, Lembeck F. 1982. Distribution of capsaicin in rat tissues after systemic administration. J Pharm Pharmacol 34(4): 273275. doi: 10.1111/j.2042-7158.1982.tb04245.x

40. Lambert JD, Lee MJ, Lu H, Meng X, Hong JJ, et al. 2003. Epigallocatechin-3-gallate is absorbed but extensively glucuronidated following oral administration to mice. J Nutr 133(12): 4172-4177.

41. Amantini C, Morelli MB, Nabissi M, Cardinali C, Santoni M, et al. 2016. Capsaicin triggers autophagic cell survival which drives epithelial mesenchymal transition and chemoresistance in bladder cancer cells in an Hedgehog-dependent manner. Oncotarget 7(31): 50180-50194. doi: 10.18632/oncotarget.10326

42. Chen X, Tan M, Xie Z, Feng B, Zhao Z, et al. 2016. Inhibiting ROSSTAT3-dependent autophagy enhanced capsaicin-induced apoptosis in human hepatocellular carcinoma cells. Free Radic Res 50(7): 744-755. doi: $10.3109 / 10715762.2016 .1173689$ 